\title{
Stage 0 Ampulla of Vater Cancer AJCC v7
}

National Cancer Institute

\section{Source}

National Cancer Institute. Stage O Ampulla of Vater Cancer A/CC v7. NCI Thesaurus. Code C4444.

Stage 0 includes: T is, N0, MO. T is: Carcinoma in situ. N0: No regional lymph node metastasis. M0: No distant metastasis. (from AJCC 7th Ed.) 